\title{
Planning Office and Community Influence on Land-Use Decisions Intended to Benefit the Low-Income: Welcome to Chicago
}

\author{
Yan Dominic Searcy \\ Chicago State University, USA \\ Correspondence should be addressed to Yan Dominic Searcy; ysearcy@csu.edu
}

Received 2 February 2014; Revised 14 May 2014; Accepted 26 May 2014; Published 10 July 2014

Academic Editor: David Wong

Copyright (C) 2014 Yan Dominic Searcy. This is an open access article distributed under the Creative Commons Attribution License, which permits unrestricted use, distribution, and reproduction in any medium, provided the original work is properly cited.

\begin{abstract}
This study explores urban planning office and community influence on land-use decision making in two poverty-stricken but redeveloping neighborhood areas in Chicago. The Department of Planning and Development in this study had marginal impact on land-use decisions due to administrative limitations. Community influence is moderated by the degree to which low-income housing advocates can act directly as developers and produce housing units. The research findings indicate that land-use decisions intended to benefit the low-income resulted not from community-based political conflict but more so from community organization cooperation with political actors.
\end{abstract}

\section{Purpose of the Study}

Much of the literature on poverty focuses on federal level initiatives as a response to urban poverty, seeming to ignore local level political processes. Researchers have tended to accept Peterson's [1] contention that cities will not redistribute their own resources and that actual redistribution, utilizing monies from taxes from upper income groups to support initiatives that benefit lower income groups, can only occur with federal assistance $[2,3]$. As a result, scarce attention has been given to policy efforts that utilize local resources that are intended to address urban poverty. A few researchers, mainly urban planners, suggested that it is possible to address poverty at the local level but offered little substantiation of what could be done or what was done [4-7].

Urban planning researchers Mayer [4], Pierre [5], and Wong [6] suggest that planning offices and community involvement can influence local policy decisions so that they benefit low-income urban residents. The researchers also suggest political conditions which may allow for policy innovations that can be couched in technical and bureaucratic processes that may yield potential benefits for lowincome residents. However, missing from the literature are examinations of instances of planning office and community influence on the use of local resources to address urban poverty.

Broadly, this study explores a local policy effort that utilized land as a local resource with the stated intention to address urban and neighborhood-based poverty. Specifically, the study (1) examines to what degree and under what conditions the Chicago Department of Urban Planning and communities influenced decision making regarding land use for low-income residents through an analysis of two neighborhood areas in Chicago from 1990-1997. The hypothesis proffered is that community-based political conflict would be the factor that influenced the degree to which land-use decisions would benefit low-income residents. This research follows Clark's [7] suggestion not only to consider model cities but also to study how particular policies are shaped and made.

\section{Methodology}

Contact between planning offices and communities generally occurs during neighborhood revitalization or redevelopment efforts. Although urban poverty is neighborhood-based, revitalizing urban neighborhoods is not implicitly an exercise in addressing poverty for two major reasons. First, not all 
neighborhoods undergoing revitalization are low-income. Second and most importantly, revitalization aims to eliminate or prevent urban blight but not to ameliorate poverty. As the literature on gentrification indicates, those neighborhoods with low-income residents that are undergoing redevelopment often simultaneously experience displacing the poor $[8,9]$. Responding to displacement of the poor, community organizations have attempted to influence policies to balance redevelopment by advocating for low-income housing for the poor in neighborhood areas undergoing redevelopment. The intersection where both planners and communities come together during revitalization efforts is the neighborhood.

To explore urban planning office and community influence on land-use decision making, two Chicago neighborhood areas undergoing revitalization, Woodlawn and Kenwood, were studied. The Chicago Department of Planning and Development was active in both neighborhoods and produced redevelopment plans and conservation plans for the respective neighborhoods. The study areas also provided instances where the Department approved land uses that intended to benefit the low-income. Both neighborhoods were also home to community organizations that attempted to influence redevelopment efforts and land-use decision making.

A qualitative study of Woodlawn and Kenwood in neighborhood areas in Chicago is employed to address the research questions. Primarily because of the exploratory nature of the research and the inability to manipulate variables, a qualitative analysis is employed as an attempt to examine the dynamics and the degree of Department of Planning and Development (referred to here as the "Department") and community influence on land use. Influence of the Department is operationalized as departmental initiated land utilization that directly benefits the low-income. Community influence as utilized in this study is limited to referring to neighborhood-based organizations that utilized land to produce units of low-income housing. Merely focusing on the ability to impact outcomes does not yield an authentic assessment of influence. Influence is most accurately measured through an assessment of outcomes. That is, influence is best discerned through assessing the degree to which lowincome units were produced.

To avoid selection bias which may predetermine the outcome of the study, the neighborhood areas were selected because of the presence of the independent variables, a planning office (the Department) and community organizations, rather than incidences of the production of lowincome units [10]. The two neighborhood areas Kenwood and Woodlawn manifest the presence of both an urban planning office and community organizations. They were selected for this reason, not because they manifest land-use decisions that have resulted in the development of units of low-income housing. Doing so would have led to selection bias.

Though the use of only two study areas may serve to limit the generalizability of the results, the limited focus was intended to lead to more detailed, robust research than research that involves multiple case studies. Chicago is studied because as the third largest city in the United States its dynamics are arguably similar to a number of major US cities and therefore may lead to generalizability to cities such as New York, Cleveland, and Milwaukee that have had to address urban decline and revitalization demands. Limiting the generalizability of the study, however, is the uniqueness of Chicago political life that reflects the persistence of machine governance combined with elements of regime politics. One recent study labeled Chicago as reflecting a "mayor-centered neoclientelism." [11] At the outset of the study period from 1990 to 1997 the presiding mayor Richard M. Daley (a son of long-term machine mayor Richard J. Daley) was one year into his 22-year tenure as the city's chief.

The time period from 1990 to 1997 reflects a need to address urban political dynamics that have received little qualitative or quantitative study and include the emergence of what Clark [7] labelled as a new political culture. The researcher's proximity and access to pertinent research resources are also factors that influenced the selection of Chicago as the focus of the study.

In this study, community is operationalized as nonprofit neighborhood-based organizations that serve and advocate for residents of a neighborhood. A problematic in discussions of community influence is the concept of "community." A caution is issued, therefore, that community influence as utilized in this study is limited to referring to the neighborhoodbased organizations that were able to produce units of low-income housing. It can be argued that community organizations that may not have near unanimous support from neighborhood residents do not represent communitywide influence. Community, therefore, may only represent those members who are the most organized, not the most numerous.

The study utilizes the federal definition of low-income family incomes that are 65 percent or less than the Primary Metropolitan Statistical Area (PMSA) median income. During the study period the Chicago PMSA median income for a family of four was $\$ 41,745$. Low-income families, therefore, would have incomes at or below $\$ 27,134$. Housing structures that are considered low-income must not exceed 33 percent of the family income. Based on federal standards, an affordable rent or mortgage for a family of four should cost no more than $\$ 747$. In order to give context to understanding redevelopment initiatives during the study period from 1990 to 1997, a detailed history of Woodlawn and Kenwood is provided below.

\section{The Neighborhoods}

Through a series of transitions and a process of divestment Woodlawn and Kenwood became like fossils, skeletal and lifeless, but left with the imprint of what were once vibrant and thriving neighborhoods. By the late 1980s, both neighborhoods began revitalization efforts.

3.1. Woodlawn. Woodlawn lies approximately eight miles south of downtown Chicago.

The area's population peaked in the 1950s with 80,699 residents. The 1950s also marked the beginning of the transition of the German and Irish neighborhood to one almost exclusively Black. Though the 1960s marked Woodlawn as 
a figuratively fiery period of community activism, the 1970 s was literally a fiery period for Woodlawn. The neighborhood experienced an unusual amount of fires. In 1970, there were 1,600 reported fires within the eastern section of Woodlawn [12].

The 1980s delivered Woodlawn another blow with increasing numbers of vacant lots, abandoned buildings, and increasing violence as crack cocaine changed the dynamics of street and gang crime. The neighborhood became a lab for poverty researchers and journalists $[13,14]$. Between 1970 and 1980 Woodlawn suffered a loss of 6,477 units of housing and 32 percent of its already diminished population $(36,323$ residents in 1980) (Community Development Report 1992).

By 1990, over 40 percent of the eastern section of Woodlawn was vacant while slightly over 25 percent (1,169 vacant lots) of the entire neighborhood area was vacant (Community Development Report 1992). Woodlawn businesses numbered about 100. Thirty years before, the number was nearly 800 . In 1990, over 53 percent of Woodlawn households made less than $\$ 15,000$.

3.2. Kenwood. Kenwood, as referred to in this study, is actually the agglomeration of two contiguous neighborhood areas (North Kenwood and Oakland) whose histories are closely related. Residents and the Department consider the area to be one neighborhood, North Kenwood-Oakland, despite being municipally identified as two distinct neighborhood areas. Below, a brief history of both Kenwood and Oakland is provided in order to provide understanding of the dynamics that led to the decline of the neighborhoods and also to identify how they came to be considered as one neighborhood area.

3.3. North Kenwood. Kenwood is located approximately four and one-half miles south of Downtown Chicago and borders Lake Michigan to the east. In 1950, Kenwood was 10 percent Black. By 1960 the area was 84 percent Black. In 1956 the southern, more affluent and white end of Kenwood was designated as a conservation area and annexed as part of the Hyde Park-Kenwood Conservation Area (HPKCA). Implementation of the HPKCA plan brought massive demolition and divestment in the northern section of the neighborhood (Community Fact Book 1995).

During the 1970s, the area continued to suffer from divestment. The population that remained, 26,908 (a 36 percent drop in ten years), experienced increasing numbers of arson and abandonment, dilapidated housing ignored by absentee landlords, and increasing crime and violence. The 1980 s greeted the neighborhood with a population drop to 22,000 and a continuation of the trends of abandonment and dilapidation of the 1970s. By 1990 the overall population of Kenwood had decreased to 18,000 . The racial composition became 97 percent Black. Approximately 37 percent of its residents made less than $\$ 15,000$.

3.4. Oakland. By the 1950s, the population of the area swelled to more than 24,000 (up from 15,000 in 1930) as a result of the growth of the Black population in the area. To address housing shortages, new construction was of public housing. Several housing projects were built in the area, concentrating low-income residents [12]. By 1960, the area was 98 percent Black. Toward the end of the 1960s, an urban renewal project razed one-fourth of the housing in the area and left the land vacant for nearly two decades.

By 1970, the area manifested the qualities of a slum, dilapidated and vacant housing, high concentrations of public housing, and high crime rates. In 1980, 71 percent of the total housing units in Oakland were publicly assisted. The 1980s, however, marked the beginning of redevelopment in Oakland as a public housing project was converted to mixed-income housing. Though redevelopment began, two of the five census tracts in Oakland ranked among the lowest income areas in the United States in 1990 as family median income was recorded to be below $\$ 5,400$ for both tracts. In 1990 , the population decreased to 8,197 . Mean household income was $\$ 10,849$. Slightly over 72 percent of Oakland's population was in poverty.

\section{Hands to the Clay: Influence}

Land-use decision making involves more than planners and community organizations. The role of the mayor and alderman cannot be marginalized. Therefore, a brief discussion of the influence of the mayor and aldermen is provided before Departmental and community organization influence is addressed.

4.1. Mayoral Influence. Redevelopment must have the mayor's direct sanction. It is nearly impossible that any redevelopment could occur in Chicago without mayoral approval. Through appointment powers, the mayor has the ability to influence the land-use decision making process. The mayor appoints

(i) the commissioner of the Department,

(ii) the commissioner of the Department of Housing (as well as other city posts),

(iii) members to the Urban Renewal Board,

(iv) members to the Community Development Commission,

(v) members to the Chicago Plan Commission on which the mayor sits,

(vi) members to the Neighborhood Planning Council,

(vii) members to the Conservation Community Council.

The mayor also can remove appointments at his discretion. By virtue of his appointment powers, the mayor guarantees that his development interests will be primary.

Although the mayor may not produce actual development plans, his desires are manifested in the activities or lack of activities of the Department. Mayoral influence is also displayed as a budgetary issue as the mayor may allocate or fail to allocate funds for particular Departmental initiatives. Corporate funding to the Department from 1990 to 1991 reflected an over 30 percent increase. The amount remained relatively consistent through 1997. 
4.2. Aldermanic Influence. An alderman in this study can best be understood as a mayor of a ward/community. The decisions that are made within the boundaries of the ward must be approved by the alderman. Related to land use, the alderman has the ability to "hold" city owned land. That is, Chicago Aldermen can restrict the sale of cityowned properties within their wards. According to a planning official, "if the alderman does not push (a development plan), it does not matter who screams and hollers."

\subsection{Planning Office Influence: A developer Driven Planning} Office. In neighborhood redevelopment efforts, the Department is dispatched by the mayor and by aldermen. Developer interests, however, drive the planning process. As one Department official related, the Department is not composed of planning renegades who have the autonomy to canvas the city looking for areas to redevelop and then dictate the plans.

Although acknowledging that the mayor has a significant degree of power over the urban planning process, the official underscored the mayor's limitations, "the mayor can do what he wants, but (he) cannot do it without depending on developers." The same official added, "you cannot force a developer to come; the planning office cannot work on long term (development) and do land assemblage." The Department's residential planning goal is to assist the housing market by creating incentives for investment and then allowing market forces to direct the process. As the market sustains itself, the Department suspends its activities in a particular area.

The Department attempts to attract development with a number of joint tools: (1) studies to determine whether land use is to be commercial or residential or to change land use; (2) acquisition of property for tax reactivation by the Department Of Housing (DOH); (3) suggestions that land parcels are appropriate for housing based on the findings of preliminary studies; (4) composing redevelopment plans; and (5) composing conservation plans. The Department provided land surveys and zoning data, coordinated meetings, and carried out the overall administration of development. These activities represent the technical, professional process identified in the planning literature (Rabinovitz 1969; $[5,15]$ ). Though the literature suggests that through the planning process, a planning office can influence land-use decisions intended to benefit the low-income, Chicago's Department focused on physical planning issues, not on issues of social equity.

In Kenwood, the Department saw the opportunity to "create something worthwhile" because vacant land was plentiful. City planners saw the redevelopment of Kenwood as potential to make a significant contribution to urban redevelopment. A planning official related,

redevelopment was something that could be done and (land) was there and it was available to be done. The mayor did not hold it up... at the time there was no real politics in the Department. Some people think that underhanded stuff was going on but this is not always the case.

\section{The Decision Making Process}

5.1. In Woodlawn. Woodlawn community redevelopment was initiated largely by a request from the Woodlawn Preservation and Investment Corporation (WPIC) which had been working on a number of development projects. Rev. Arthur Brazier, the chairman of the board of WPIC, attended to garnering city approval of the WPIC produced redevelopment plans. Brazier was a long-time community activist in Woodlawn whose history was tied to pastoring a Woodlawn storefront church and cofounding the seminal community organization The Woodlawn Organization (TWO) in the 1960s. By 1990, Brazier's storefront church had swelled to a membership of over 10,000 and was soon to begin building a multimillion dollar church on one full block in Woodlawn (completed in 1992). Also by 1990, TWO had grown into a multiservice organization that managed a multimillion dollar budget. Brazier became the central decision maker for three community organizations in the neighborhood: WPIC as chairman of the board, TWO as the organization's cofounder and former chairman of the board, and the Fund as chairman of the board.

According to a Departmental official who is also a Woodlawn resident, The Fund was created as a quasipublic development organization that was given oversight over development in the area (by the Department). The Fund's support from City Hall and its resulting influence is manifested in the organization's de facto control of Woodlawn redevelopment plans. That control manifested itself in the Fund securing the ability to be both a developer and to award development grants. The Fund and WPIC essentially became the "community." The Department accepted its proposals as a reflection of community desires.

The Fund and WPIC and Brazier were not the only community organizations in Woodlawn. They, however, were the most organized. Woodlawn East Community and Neighbors (WECAN) was a staunch advocate for low-income residents in Woodlawn. It was not represented on the board of directors of the Fund, and it was generally opposed to much of the redevelopment that targeted attracting upper middle-class residents to the area, labelling it gentrification.

The executive director of WECAN, Mattie Butler, was leery of City Hall and its activities. WECAN was outside of the community planning process until community-wide meetings were held. As a result, WECANs input into the overall redevelopment planning process was negligible. Butler noted that her organization has had no influence on City Hall. She reflected, "we do not have a phone with a line right to the mayor's office. Brazier does." If there is influence she continued, "we have microscopic influence, like throwing a pebble into the sea and the effects ripple outward." Butler suggested that their influence has been concerning bringing attention to the need for creating citywide affordable housing, helping secure empowerment zone status for the neighborhood status, and completing research on empty land in the area.

In 1991 WPIC approached the Chicago Department of Housing (DOH). (At that time a number of current Department functions were housed in the $\mathrm{DOH}$.) The $\mathrm{DOH}$ was 
impressed with the organization of the plans and alternately enthusiastic with the prospect of pursuing the plans. Feasibility and land-use studies were completed by the Department in 1992 to augment the somewhat general WPIC plans.

According to a Department official, Brazier's relationship with Chicago Mayor Richard M. Daley translated into influence on the planning process. According to the Department official, the reason why the city was supportive of WPICs plan was because it contained a "well-formed idea" and it was comprehensive. In addition, WPIC completed much of the necessary planning work by having consultants and architects develop the plans in advance.

The Department official recounted, "there were many compelling reasons to do (redevelopment), it was not only Brazier's influence, but it was logical." Redevelopment also reflected the mayor's redevelopment policy that favored mixed income housing. Brazier promoted market-rate housing construction and rehabilitation of multifamily units for affordable housing.

5.2. The Kenwood Process. Kenwood had been the subject of redevelopment plans from the city of Chicago since the 1960s. However, according to Bob Lucas, executive director of the Kenwood Oakland Community Organization (KOCO), "none ever materialized because of lack of political will and community support, more so from lack of political will."

In 1989, the City clearly articulated its interest in redeveloping the area: "given the growing outside interest in the neighborhood, it became important that the community and the City, which owns a large percentage of the vacant land in the area, get out in front of events to ensure that any future development in North Kenwood-Oakland is responsive to the needs and goals of local residents (North Kenwood Oakland Neighborhood Planning Process Community Planning Committee Report 1989, p.5) [16]." The outside interest refers to a private developer who conceived a concept plan in 1987 for developing part of the neighborhood that shouldered the lake. (The developer was said to have noticed that the area was the only undeveloped lake front property in the city while flying over Chicago and wanted to build upscale housing near the lake). In addition, the Department also had part of the neighborhood designated as a blighted and vacant project area in order to "dampen private speculation as well as to protect the City's substantial investment in housing rehabilitation in the area" (North Kenwood Oakland Neighborhood Planning Process Community Planning Committee Report 1989, p.5). [16].

Doug Gills, a member of KOCOs board of directors, echoed the sentiments of WECANs Mattie Butler who noted the influence of the Fund compared to KOCO. Gills related that the leader of the Fund, Victor Knight, "could go in (the Mayor's office through) the Mayor's elevator when KOCO had to go through the front door.... Knight and Brazier designed the Woodlawn Redevelopment plan." Indicating the influence of the Fund, Lucas of KOCO lamented, "(KOCOs) proposals may take a year (to be reviewed by the Department), if Brazier does it, it will be done in 30 days."

In Kenwood, community efforts garnered a Conservation Area designation in 1992. The designation gives the City eminent domain powers to acquire privately held vacant land that could be used to encourage the development of new housing. Importantly, the designation mandates the creation of a Conservation Community Council (CCC) which assists the Department in the development of a neighborhood conservation plan and must approve land-use proposals in the conservation area. Illinois State Legislation grants the CCC only advisory powers; however, in practice, the CCC approves or rejects land-use plans on city owned land. Not by de jure action but by de facto action, the CCCs decisions are accepted by the Department and the mayor as fiat.

In Kenwood, the CCC is the community organization that has the most influence on land-use decision making in Kenwood; however, it was not instrumental in making landuse decisions that were intended to benefit the low-income. It favored development of market rate housing and resisted any subsidized housing. Only community service oriented organizations similar to KOCO were able to influence the creation of housing for the low-income by creating the housing itself as a developer. The CCC, unlike the Fund operating in Woodlawn, was barred by state law from acting as a developer. Although land use that is intended to benefit the low-income is included in the Conservation Plan, the CCC favored the development of market-rate, unsubsidized housing in Kenwood.

\section{Finishing Touches: Outcomes of the Process}

Listed on Table 1 are the units of housing produced by community organizations. Low-income housing units composed 22 percent of the total units produced among community organizations. Affordable/moderate income refers to family incomes that are 80 percent or less than PMSA median income. Affordable/moderate income families would therefore have incomes at or below $\$ 33,396$ and have rents or mortgages no more than $\$ 918$. Market rate housing refers to housing that approximates the average of housing purchase or rental prices across the PMSA for similarly constructed structures and locations. Included in the table are community nonprofit organizations that produced units of housing during the study period.

6.1. Covenant Community Development. Covenant rehabbed many units that ranged from one single family home to multiunit buildings. It was financed with HUD Hope III money and the Chicago Abandoned Property Program (CAPP) in which the city transferred abandoned properties to parties who will renovate the property. It has also renovated a 10unit building, and a 6-unit coop, and a rent assisted unit as affordable housing. Covenant as land owner in the development also partnered with WPIC and a private developer in a program that offers homes beginning at $\$ 200,000$.

6.2. The Fund. The Fund partnered with a private developer to rehab two vacant buildings into 102 rental apartments from 1 to 3 bedroom units that were financed through a private bank, the DOH, Federal Home Loan Bank, Illinois Housing Development Authority (IHDA), and an Empowerment 
TABLE 1: Total units produced by community organizations in Woodlawn and Kenwood by Category from 1990 to $1997^{*}$.

\begin{tabular}{|c|c|c|c|c|}
\hline Community organization & Low income $\mathrm{a}^{\mathrm{a}}$ & Affordable/moderate ${ }^{\mathrm{b}}$ & Market rate $^{c}$ & Total units \\
\hline \multicolumn{5}{|c|}{ Woodlawn } \\
\hline WPIC & & 287 & 80 & 367 \\
\hline The fund & & 122 & & 122 \\
\hline WECAN & 52 & 24 & 17 & 93 \\
\hline Covenant development & 1 & & 16 & 17 \\
\hline TOTAL & 53 & 433 & 114 & 600 \\
\hline PERCENT & 9 & 72 & 19 & \\
\hline \multicolumn{5}{|c|}{ Kenwood } \\
\hline $\mathrm{KOCO} / \mathrm{KODC}$ & 117 & 233 & & 350 \\
\hline TIA & 78 & 79 & & 157 \\
\hline Ariel foundation & 2 & & & 2 \\
\hline Urban league & & & 25 & 25 \\
\hline TOTAL & 197 & 312 & 25 & 534 \\
\hline PERCENT & 37 & 58 & 5 & \\
\hline \multicolumn{5}{|c|}{ Neighborhood totals } \\
\hline TOTAL & 250 & 745 & 139 & 1,134 \\
\hline PERCENT & 22 & 65 & 12 & \\
\hline
\end{tabular}

Notes. ${ }^{\mathrm{a}}$ Low income refers to family incomes that are 80 percent or less than the Primary Metropolitan Statistical Area (PMSA) median income.

${ }^{\mathrm{b}}$ Affordable/moderate income refers to family incomes that are 80 percent or less than PMSA median income.

${ }^{\mathrm{c}}$ Market rate housing refers to housing that approximates average of housing purchase or rental prices across the PMSA for similarly constructed and located structures.

${ }^{*}$ Figures provided by community organizations active in neighborhood areas.

Zone grant. It has also completed new home development tagged as affordable with homes ranging from $\$ 99,000$ to 150,000. The developments were funded through a New Homes for Chicago program where developers received a $\$ 30,000$ subsidy per home from the City to keep housing affordable.

6.3. WPIC. WPIC partnered with a private developer and rehabbed six vacant buildings into 117 units of Low-Income Housing Tax Credit housing with "very low rents" under the Affordable Rents for Chicago (ARC) program. It is financed through the DOH, HOME program, The Federal Home Loan Bank, and the Chicago Equity Fund. The \$12 million renovation project was a joint venture with Neighborhood Reinvestment Resources, the Chicago Low-Income Housing Trust Fund, Chicago Equity Fund, private lenders, and the use of Low-Income Tax Credits. More than 70 percent of the initial residents in the buildings lived in Woodlawn before moving into the buildings. Nearly 65 percent of the residents had income below $\$ 18,000$.

In a similar joint venture as above, WPIC rehabbed seven buildings into 84 total units that included studio and one-bedroom apartments. Renovations were funded by a private bank, the National Equity Fund, and the Federal Home Loan Bank. Another development of 86 rental units was orchestrated by using Low-Income Housing Tax Credits coupled with financing from IHDA and the Chicago Equity Fund.

6.4. KOCO/KODC. The majority of KOCOs developments were for the low and moderate income. The development arm of KOCO is the Kenwood Oakland Development Corporation (KODC). Of the 350 units KODC developed, 70 were new construction. A project which produced 117 units for low-income families in 6 buildings was financed by $\mathrm{DOH}$ $\$ 2.5$ million in CDBG funding to City Lands Community Investment Corp, The Illinois Affordable Housing Trust Fund, and the National Equity Fund. Annual income of the tenants ranged between $\$ 5,000$ and $\$ 10,000$.

6.5. Chicago Urban League. The Chicago Urban League was focused on providing new affordable homes to families in Kenwood. The homes started at $\$ 94,500$. It was financed through a private bank and DOH New Homes for Chicago housing subsidies.

6.6. Travelers and Immigrants Aid (TIA). TIA, a nonprofit social service agency based outside of Kenwood that serves the entire city of Chicago, partnered with a private developer in a 157-unit rehab of the former Sutherland Hotel. The units for the low and moderate income were financed without direct federal funds as TIA placed $\$ 800,000$ of equity into the project. Oakwood development Co., a private rehab and construction company that orchestrated the project, added $\$ 300,000$. The Chicago Equity Fund, which places corporate money to low-income housing development projects by syndicating low-income tax credit benefits, provided $\$ 1.2$ million. IHDA loaned \$500,000.

6.7. Ariel Foundation. The Ariel Foundation, a not for profit philanthropic organization, built two affordable single family 
homes priced to sell at $\$ 74,000$ to families earning between $\$ 24,000$ and $\$ 36,000$ a year. The buyers were to be selected by a committee of local residents, religious leaders, and representatives from the foundation [17]. The housing development incorporated youth who assisted with construction as part of a Careers for Youth program. The foundation collaborated with Uptown Habitat for Humanity as the development's construction company and Careers for Youth as the general contractor which incorporated high school students as laborers.

\section{Research Findings}

Overall, land-use decision making is subject to the political will of the mayor. At the neighborhood level, land-use decisions are based on the interaction of several factors that include aldermanic preferences, the availability of land, secured funding for development on the land site, and community approval.

7.1. Independence versus Influence. The Department's direct influence over land use is minimal as it is limited by mayoral directives and is moderated by developer interests and community participation. The Department responds to directives; it does not set policy. An example of these directives is in the creation of the Fund. In Woodlawn, Rev. Brazier had the support of Mayor Daley who shared a desire for mixed-income redevelopment and Valerie Jarrett, the then commissioner of the Department, who was an appointed official, not a trained, professional planner. Others at the Department, nonmayoral appointees and professional planners, were concerned about possible conflict of interests issues as the Fund wanted to be a "clearinghouse" for redevelopment plans as well as being a developer. According to an official at the Department, at one time, it was Brazier's desire for the Fund to be the only developer in the area. Ultimately the Fund was granted the ability to award development grants as well as to act as a developer.

Daley and WPIC shared desires of creating mixed-income redevelopment that focused on the building or rehabbing of single family homes. In November 1993, Daley announced at a ground breaking for 28-market-rate single family homes, "it has to be mixed. You cannot go back to the old way of rich and poor [18]."

7.2. General Plans and the Role of the CCC. The Woodlawn Redevelopment Plan and the North Kenwood Oakland Conservation plans suggested that efforts should be made to utilize land for the provision of housing for the low-income. Neither plan contained specific provisions for the creation of low-income housing. A percentage of development intended for low-income or specific numbers of units to be built were not included. The plans, which also lacked specific numbers or percentages for the development of market rate or other housing, were broad in scope. Though no specific provisions were made, the plans did, however, create a framework for redevelopment that included the use of land intended to benefit low-income residents. The plans suggested mixedincome development. The units to be developed for the low-income were to result from the efforts of nonprofit community organizations and to a limited extent from profit developers.

In Kenwood, land-use proposals which were to bring new housing that was priced $\$ 150,000$ or above met little, if any, resistance from CCC members, as long as developers and contractors met minority and women participation rates. Affordable housing plans received resistance to the extent that some CCC members were reluctant to approve landuse plans that allowed for the building of "cheap" housing. What received substantial CCC and community resistance were scatter site housing plans. Proposed in late 1995, a plan to locate 241 scatter-site HUD/CHA subsidized units in Kenwood was opposed by the CCC. The CCC was not dedicated to making decisions to utilize land for the lowincome. Members of the CCC were reluctant to approve 26 units of low-income housing, down from the original plan of 241 scatter-site units. In effect, the CCC was used as a tool to protect and increase property values of property owners.

7.3. Community Developers. The research revealed that only those community organizations that act in the role of developer have influence on the decision making process that results in land use for the low-income. As developers, community organizations must have specific plans for land use and secured financing to develop the plans. Having a land-use plan without financing had no impact on outcomes.

In the two neighborhood study areas, Woodlawn and Kenwood, the City did not respond to low-income housing advocates who proposed that housing for the low-income should be built or respond to opposition during community meetings to plans to build upscale housing by deciding to build low-income housing. This type of community pressure may lead to inclusion and participation in the planning process but does not result in the production of low-income units.

The hypothesis of the study that suggested that land-use decisions intended to benefit the low-income would be a direct result of political conflict turned out to be erroneous. Decisions to utilize land for the intended benefit of the low-income resulted not from the degree of conflict but from the degree of cooperation between communities and political actors. The research here revealed that community groups exert influence only through participation as nonprofit developers and operate much like for profit developers in partnership with the Department. Land-use decision making followed the standard bureaucratic process of the Department: developers present plans to the Department, the Department works with the developers to refine the plans, and with financing, structures are built.

Conflict with political leaders may lead to participation in planning, but developers build housing. Community pressure produced redevelopment areas and conservation areas, not low-income housing. This finding gives rise to an alternative hypothesis that given a highly organized and mobilized protest movement, community pressure may garner more than participation [19]. 


\section{Interpreting the Piece: Summary and Implications}

Mayoral support and Departmental support for redevelopment plans were relatively easy concessions to community demands. Redevelopment would benefit the city by creating revenue from property taxes on formerly city-held land that was in the hands of developers and homeowners. Redevelopment plans helped to cement political support for Daley in two Black neighborhoods. The support would extend beyond the boundaries of Woodlawn and Kenwood as the neighborhoods mirrored other low-income areas attempting redevelopment initiatives. For the mayor, redeveloped areas would mean improved relations between neighborhoods and City Hall and better relations with Black voters. In addition, supporting redevelopment did not conflict with the mayor's preference for development that focused on attracting and retaining the middle class.

8.1. Middle Class Preferences. Woodlawn and Kenwood revealed that community participation reflected a middleclass mien. Both communities, though verbally opposed to displacement of existing residents, resisted developing lowincome housing. The question for many of the middleincome was not how to house the low-income, but how not to house them. The middle-income wished to protect their property values and viewed low-income housing as negatively affecting their property investments. Leadership and participation in planning processes also tilt toward the middle-income whose job schedules, flexibility, child care options, and communication styles facilitate inclusion. Those who have lower income tend to be hourly workers who do not have flexible schedules.

8.2. A Final Note on Community Influence. As noted, the research revealed that Departmental influence on land-use decisions is minimal and only those community organizations that act in the role of developer have influence on the decision making process that results in land use for the low-income. Participation in the urban planning process does not equal low-income housing outcomes. However, the study revealed that, in Kenwood, where community-wide participation was involved, more low-income housing units were produced than in Woodlawn where community-wide participation in planning was negligible. A KOCO official remarked that Kenwood's process stands in stark contrast to that which occurred in Woodlawn. The development plans were discussed in one community meeting and "the public process came in the form of: "here is the development plan and what color would you like the cover to be?"'

\section{Conflict of Interests}

The author declares that there is no conflict of interests regarding the publication of this paper.

\section{References}

[1] P. Peterson, City Limits, The University of Chicago Press, Chicago, Ill, USA, 1981.
[2] C. Stone, Regime Politics: Governing Atlanta 1946-1988, University Press of Kansas, Lawrence, Kan, USA, 1989.

[3] W. Wiewel and P. Nyden, Eds., Challenging Uneven Development: An Urban Agenda for the 1990's, Rutgers University Press, New Brunswick, NJ, USA, 1991.

[4] R. R. Mayer, Social Planning and Social Change, Prentice Hall, Englewood Cliffs, NJ, USA, 1972.

[5] P. Clavel, The Progressive City, Rutgers University Press, New Brunswick, NJ, USA, 1986.

[6] K. Wong, City Choices: Education and Housing, State University of New York, Albany, NY, USA, 1990.

[7] T. N. Clark, Ed., Urban Innovation: Creative Strategies for Turbulent Times, Sage Publications, Thousad Oaks, Calif, USA, 1994.

[8] B. London and J. J. Palen, Gentrification, Displacement, and Neighborhood Revitalization, State University of New York Press, Albany, NY, USA, 1984.

[9] K. Newman and E. K. Wyly, "The right to stay put, revisited: gentrification and resistance to displacement in New York City," Urban Studies, vol. 43, no. 1, pp. 23-57, 2006.

[10] G. King, R. O. Keohane, and S. Verba, Designing Social Inquiry: Scientific inference in Qualitative Research, Princeton University Press, Princeton, NJ, USA, 1994.

[11] W. Sites, "God from the machine? Urban movements meet machine politics in neoliberal Chicago," Environment \& Planning, vol. 44, no. 11, pp. 2574-2590, 2012.

[12] Melaniphy and Associate, Chicago Comprehensive Needs Analysis, Melaniphy and Associates, 1982.

[13] W. J. Wilson, The Truly Disadvantaged: The Inner City, the Underclass, University of Chicago Press, Chicago, Ill, USA, 1987.

[14] N. Lemann, "The myth of community development," The New York Times Magazine, 1994.

[15] E. J. Kaiser, D. Godschalk, and F.S. Chapin, Urban Land Use Planning, University of Illinois Press, Chicago, Ill, USA, 4th edition, 1995.

[16] North Kenwood Oakland Neighborhood Planning Process Community Planning Committee Report, Department of Planning, City of Chicago, 1989.

[17] F.F. Rabinovitz, City Politics and Planning, Atherton Press, New York, NY, USA, 1969.

[18] E. Michaeli, Daley Announces Rebirth of Woodlawn Area, The Chicago Defender, 1993.

[19] W. Sites, "Public action: New York City Policy and the gentrification of the lower East side," in From Urban Village to East Village: The Battle for New York's Lower East Side, J. Abu-Lughod, Ed., Blackwell, Oxford, UK, 1994. 

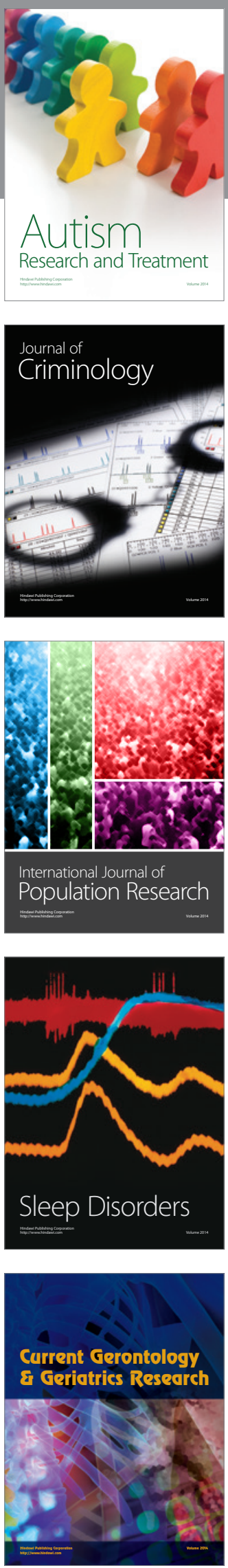
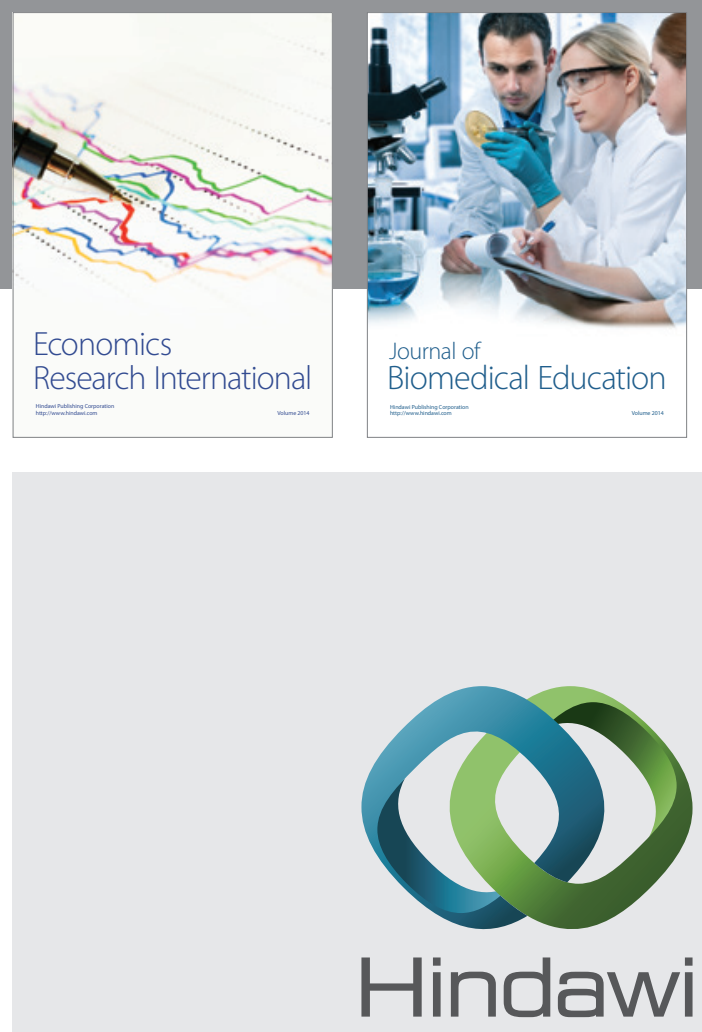

Submit your manuscripts at

http://www.hindawi.com
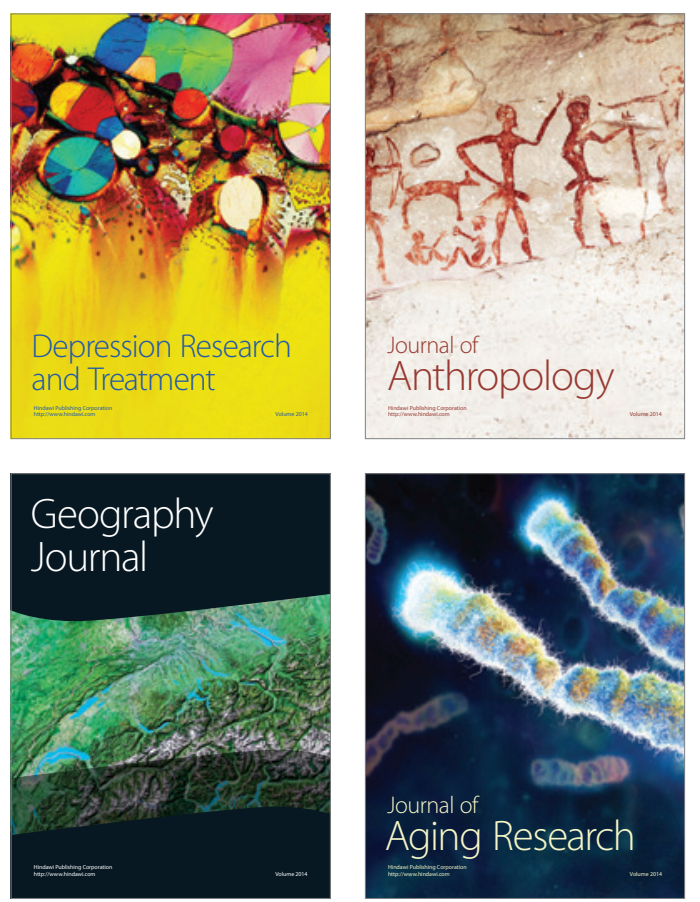
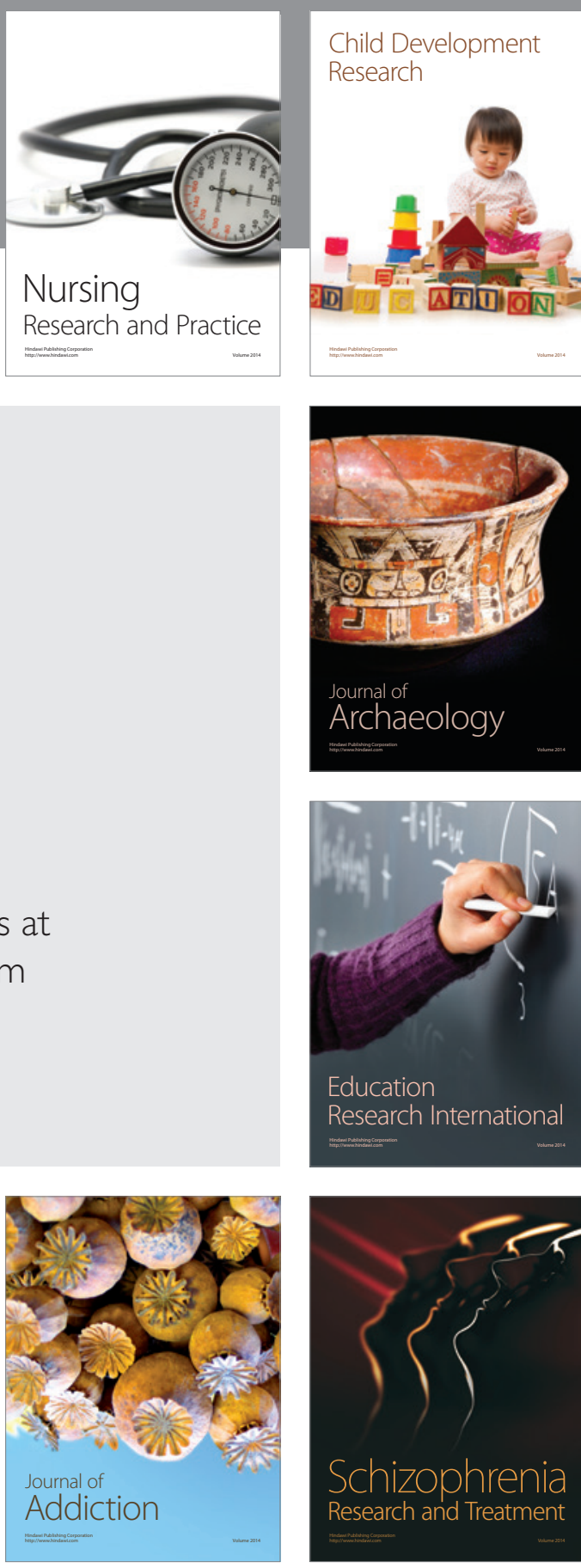

(D)
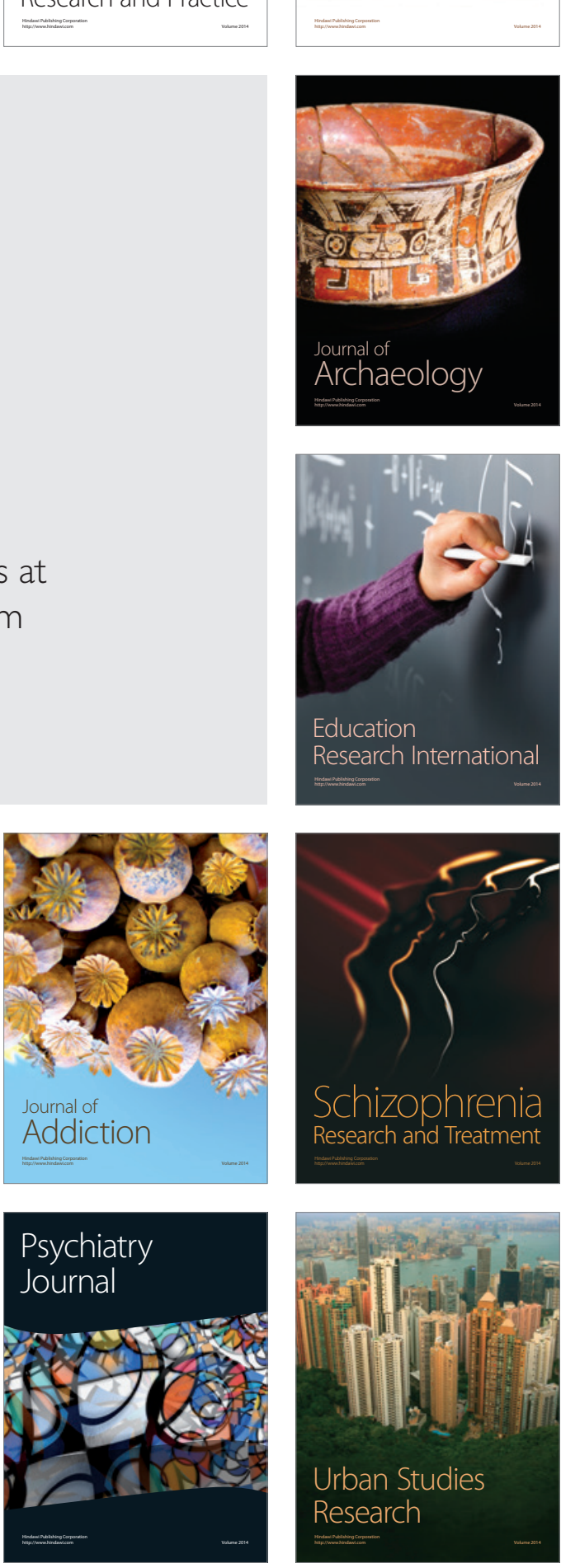